\section{Effect of cocaine on the contracture response to $1 \%$ halothane in patients undergoing diagnostic muscle biopsy for malignant hyperthermia}

Nobuyoshi Sato MD, ${ }^{*}$ Jose M. Brum MD, Hiroshi Mitsumoto MD, $\dagger$ Glenn E. DeBoer MD
Two case reports hove cited the recreational use of cocaine as possible trigger of a malignant hyperthermia (MH) crisis. We evaluated whether toxic concentrations of cocaine altered the in vitro muscle response to halothane during contracture tests for MH. Twenty-two patients were studied. Muscle biopsies were obtained and first tested for MH susceptibility with $3 \%$ halothane and caffeine contracture testing. Ten patients were diagnosed as $M H$-susceptible and 12 as $M H$ non-susceptible, in accordance with the North American Malignant Hyperthermia Group protocol. Then, muscle strips were exposed to $1 \%$ halothane in the presence and absence of $0.1 \mathrm{mmol} \cdot \mathrm{L}^{-1} \mathrm{co}-$ caine. Cocaine alone did not affect baseline muscle tension in either group. With 1\% halothane, $M H$ non-susceptible muscle showed no contracture with or without cocaine. In contrast, in the presence of $1 \%$ halothane, MH-susceptible muscle showed either no change in contracture (six patients), an increase (two patients), or a decrease (two patients) when exposed to cocaine. However, the overall effect of cocaine on muscle contracture in the presence of $1 \%$ halothane was insignificant in both groups. We conclude that cocaine, even at toxic levels,

\section{Key words}

ADDICTION: cocaine;

ANAESTHESIA, LOCAL: cocaine;

HYPERTHERMIA: malignant.

From the Division of Anesthesiology and †Department of Neurology, Cleveland Clinic Foundation, 9500 Euclid Avenue, Cleveland $\mathrm{OH} 44195$.

*Visiting investigator from the Department of Anesthesiology and Critical Care Medicine, Hiroshima University School of Medicine, Hiroshima, Japan. Address correspondence to: Dr. Glenn E. DeBoer, Department of General Anesthesiology, M26, Cleveland Clinic Foundation, 9500 Euclid Avenue, Cleveland, OH 44195-5001. Accepted for publication 22nd October, 1995. does not have a direct effect on skeletal muscle contractility and thus is safe for MH-susceptible patients.

Deux observations ont déjà mentionné l'usage illégal de la cocaïne comme cause déclenchante de crises d'hyperthermie maligne (HM). Nous recherchons si des concentrations toxiques de cocaïne pourraient changer in vitro la réponse des tests de contracture musculaire à l'halothane $1 \%$ spécifiques pour l'HM. Létude porte sur vingt-deux patients. Des biopsies musculaires sont d'abord prélevées et soumises à l'épreuve de contracture à lhalothane $3 \%$ et à celle de la cafëine. Chez dix patients on diagnostique une susceptibilité à l'HM en conformité avec le protocole nord-américain du groupe d'HM alors que 12 patients sont déclarés normaux. Les lambeaux musculaires sont ensuite exposé à l'halothane $1 \%$ en présence ou non de cocaïne $0,1 \mathrm{mmol} \cdot L^{-1}$. L'exposition à la cocaïne seule ne change pas la tension musculaire initiale dans les deux groupes. Avec halothane $1 \%$, le muscle non susceptible à l'HM ne présente pas de contracture que ce soit avec ou sans cocaïne. Par contre, avec l'halothane $1 \%$, le muscle susceptible à l'HM en présence de cocaine montre aucun changement (six patients), une augmentation (deux patients) ou une diminution de la contracture (deux patients). Cependant, en général, l'effet de la cocaïne sur la contracture musculaire en présence de cocaïne $1 \%$ est négligeable pour les deux groupes. Nous concluons que la cocaïne, même à concentrations toxiques, n'a pas d'effets directs sur la contractilité du muscle squelettique et ainsi ne présente pas de danger pour les patients susceptibles à l'HM.

Loghmanee and Tobak ${ }^{1}$ reported a case of cocaineinduced fatal $\mathrm{MH}$ in a 20 -yr-old man after an evening of recreational cocaine and ethanol abuse. Furthermore, Britt $^{2}$ reported a family in which a variety of factors triggered $\mathrm{MH}$ reactions. One member died from $\mathrm{MH}$ that developed after ingestion of both alcohol and cocaine. 
Britt suggested that cocaine, ethanol, and emotional excitement contributed to the development of the $\mathrm{MH}$ crisis. She also suggested that large doses of cocaine may not be safe for MH-susceptible patients because cocaine may elevate body temperature by potentiating the responses of sympathetically innervated organs, by increasing muscle activity, and by modulating the temperature regulation centre. $^{2}$

Exposure to triggering agents induces $\mathrm{MH}$; often the triggers are anaesthetic drugs, but heat stress and emotional excitement have been implicated. ${ }^{3}$ Halothane- and succinylcholine-induced $\mathrm{MH}$ crisis is well-known in clinical anaesthesia practice. Other anaesthetics, such as enflurane, ${ }^{4,5}$ isoflurane, ${ }^{6,7}$ and sevoflurane, ${ }^{8,9}$ may also cause an MH crisis. In general, opioids, barbiturates, and the local anaesthetics, including cocaine, have been accepted as safe for MH-susceptible patients. ${ }^{10}$

Given the above case reports and that cocaine has been considered to be safe for MH-susceptible patients, we investigated whether cocaine changed the contracture sensitivity of muscle strips in MH-susceptible patients. We evaluated the effects of cocaine on $1 \%$ halothane-induced muscle contracture in patients undergoing diagnostic muscle biopsy for $\mathrm{MH}$.

\section{Methods}

\section{Patients}

Diagnostic muscle biopsies were performed in 22 patients under medical request. The remaining muscle tissue that would otherwise be discarded was used to test for the effects of cocaine. Informed consent to use the remaining tissue for research studies and to publish the results were obtained from each patient. All patients had a personal or family history of $\mathrm{MH}$. No patient was taking any medication known to influence skeletal muscle contractility.

\section{Muscle biopsy}

The muscle biopsy procedure and the muscle contracture tests were carried out according to the NAMHG protocol." For the muscle biopsy, vastus lateralis muscle was obtained using a femoral and lateral femoral cutaneous nerve block with chloroprocaine and tetracaine. Intravenous sedation was provided by fentanyl and midazolam.

\section{Measurement \\ Muscle bundles were suspended isometrically, with one end fixed to the bottom of a tissue bath and the other attached to a force displacement transducer (Grass FT 03C, Quinsy, MA). A Krebs-Ringer solution at $37^{\circ} \mathrm{C}$ was used for the bath and was aerated with carbogen}

$\left(95 \% \mathrm{O}_{2} \pm 5 \% \mathrm{CO}_{2}\right)$. Muscle tension was measured before and after addition of pharmacological agents with a Gould Recorder and Transducer Amplifier System (Gould 2200S, Cleveland, $\mathrm{OH}$ ). Muscle strip viability was verified by the response to a $5 \mathrm{msec}$, supramaximal electrical stimulation at a frequency of $0.2 \mathrm{~Hz}$. Electrical stimulations were generated by a stimulator (Grass S44, Quinsy, MA) using a pair of parallel-flanking platinum electrodes.

\section{Diagnosis}

For the diagnosis of MH susceptibility, six muscle strips were tested: the $3 \%$ halothane contracture test was done on three strips, and the caffeine dose-response contracture test was done on the three remaining strips. The criteria for a positive diagnosis were in accordance with the NAMHG recommendations: ${ }^{11}$

1 contracture $\geq 0.7 \mathrm{~g}$ after exposure to $3 \%$ halothane;

2 tension $\geq 0.2 \mathrm{~g}$ at $2 \mathrm{mmol} \cdot \mathrm{L}^{-1}$ caffeine, or a caffeinespecific concentration (CSC) $<4 \mathrm{mmol} \cdot \mathrm{L}^{-1}$ caffeine, or an increase of $>7 \%$ of maximal tension above the baseline at $2 \mathrm{mmol} \cdot \mathrm{L}^{-1}$ caffeine.

Patients were diagnosed as $\mathrm{MH}$-susceptible even if only one of his or her muscle strips demonstrated an abnormal contracture response after exposure to either $3 \%$ halothane alone or caffeine alone. ${ }^{11}$

\section{$1 \%$ halothane contracture test}

If enough tissue remained following the diagnostic tests, a $1 \%$ halothane contracture test was performed on two additional strips (one in the presence of $0.1 \mathrm{mmol} \cdot \mathrm{L}^{-1}$ cocaine and the other in the absence of cocaine) to determine whether cocaine potentiates the halothane response. The test sequence was as follows:

1 addition of $0.1 \mathrm{mmol} \cdot \mathrm{L}^{-1}$ cocaine followed by a tenminute recording interval.

2 addition of $1 \%$ halothane followed by ten-minute recording interval.

The halothane contracture test without cocaine was performed in the same sequence except that cocaine was not added. Baseline change during administration of $1 \%$ halothane was measured as evidence of the effects of halothane. The maximum time from muscle excision to testing was $4.5 \mathrm{hr}$. Cocaine hydrochloride was diluted with double-distilled water and was made fresh daily.

\section{Data analysis}

Data from the MH-susceptible and MH-non-susceptible groups were analyzed and compared by the following methods: chi-square test to study the sex distribution, Student's $\mathrm{t}$ test to compare age distribution and the \% decrease of twitch height induced by cocaine. KruskalWallis one-way analysis of variance followed by the Wil- 
TABLE Results of $3 \%$ halothane contracture test and caffeine contracture test

\begin{tabular}{|c|c|c|c|c|c|c|c|c|c|c|c|c|}
\hline \multirow[b]{3}{*}{ Patient } & \multirow{2}{*}{\multicolumn{3}{|c|}{$\begin{array}{l}3 \% \text { Halothane contracture } \\
\text { test } \\
\text { Contracture } \geq 0.7 \mathrm{~g}\end{array}$}} & \multicolumn{9}{|c|}{ Caffeine contracture test } \\
\hline & & & & \multicolumn{3}{|c|}{$C S C<4 \mathrm{mmol} \cdot L^{-1}$} & \multicolumn{3}{|c|}{ Contracture at $2 \mathrm{mmol} \cdot L^{-1}>0.2 \mathrm{~g}$} & \multicolumn{3}{|c|}{ Change in response $>7 \%$ at $2 \mathrm{mmol} \cdot L^{-1}$} \\
\hline & Strip 1 & Strip 2 & Strip 3 & Strip 1 & Strip 2 & Strip 3 & Strip I & Strip 2 & Strip 3 & Strip I & Strip 2 & Strip 3 \\
\hline S1 & 0.5 & 0.3 & $0.7 *$ & 5.4 & 6 & 4.8 & 0 & 0 & 0 & 0 & 0 & 0 \\
\hline $\mathrm{S} 2$ & 0.5 & 0.5 & $1^{*}$ & $3.7^{*}$ & 4.3 & 9.5 & 0 & 0.2 & 0 & 0 & 5.5 & 0 \\
\hline \$3 & $1.8^{*}$ & $1.9^{*}$ & $1^{*}$ & $3^{*}$ & $2.4^{*}$ & $3.4^{*}$ & $0.5^{*}$ & $0.9^{*}$ & $0.3^{*}$ & $8.8^{*}$ & $16.3^{*}$ & 5.4 \\
\hline S4 & $1.4^{*}$ & $1.5^{*}$ & 0.6 & $2.9^{*}$ & $2.9^{*}$ & $3.6^{*}$ & $0.5^{*}$ & $0.6^{*}$ & $0.5^{*}$ & $11.6^{*}$ & $12.2^{*}$ & $15.1^{*}$ \\
\hline SS & $1 *$ & 0.3 & 0.3 & 5.2 & 4 & 5 & 0 & 0 & 0 & 0 & 0 & 0 \\
\hline S6 & $2.4^{*}$ & $1.2^{*}$ & $1^{*}$ & 4.4 & $3.6^{*}$ & $3.6^{*}$ & 0.1 & 0.2 & $0.4^{*}$ & 2.4 & 3.9 & $9.5^{*}$ \\
\hline S7 & $4.1^{*}$ & $5.5^{*}$ & $1.9^{*}$ & $2.3^{*}$ & $2.2^{*}$ & $2.3^{*}$ & $0.6^{*}$ & $0.8^{*}$ & $0.7^{*}$ & 5.7 & $14.8^{*}$ & $8.4^{*}$ \\
\hline S8 & $1.1^{*}$ & $1^{*}$ & $1.6^{*}$ & 5.8 & 7 & 9 & 0.1 & 0 & 0 & 3.8 & 0 & 0 \\
\hline$\$ 9$ & $1.9^{*}$ & $1.9^{*}$ & $0.9^{*}$ & $1^{*}$ & $2^{*}$ & $0.75^{*}$ & $1.8^{*}$ & $1^{*}$ & $2.4^{*}$ & $18^{*}$ & $10.9^{*}$ & $31.2^{*}$ \\
\hline $\mathrm{S} 10$ & 0.4 & 0.4 & $0.9 *$ & $3.8^{*}$ & 5.6 & $3.4^{*}$ & 0 & 0 & 0 & 0 & 0 & 0 \\
\hline N1 & 0.1 & 0.1 & 0 & 5.6 & 12.5 & 4.4 & 0 & 0 & 0 & 0 & 0 & 0 \\
\hline N2 & 0 & 0 & 0 & 12 & 7.4 & 5.4 & 0 & 0 & 0 & 0 & 0 & 0 \\
\hline N3 & 0 & 0 & 0 & 8 & 8 & 5.3 & 0 & 0 & 0 & 0 & 0 & 0 \\
\hline N4 & 0.1 & 0 & 0 & 6.5 & 6 & 5.6 & 0 & 0 & 0 & 0 & 0 & 0 \\
\hline N5 & 0.1 & 0.1 & 0.1 & 5 & 6 & 5.4 & 0 & 0 & 0 & 0 & 0 & 0 \\
\hline N6 & 0 & 0.1 & 0.1 & 11.5 & 9.5 & 6.5 & 0 & 0 & 0 & 0 & 0 & 0 \\
\hline N7 & 0 & 0 & 0 & 15 & 11 & 13 & 0 & 0 & 0 & 0 & 0 & 0 \\
\hline N8 & 0 & 0 & 0 & 4.3 & 6 & 14 & 0 & 0 & 0 & 0 & 0 & 0 \\
\hline N9 & 0 & 0 & 0 & 5 & 7 & 11.5 & 0 & 0 & 0 & 0 & 0 & 0 \\
\hline N10 & 0 & 0 & 0 & 5 & 7 & 5.8 & 0 & 0 & 0 & 0 & 0 & 0 \\
\hline N11 & 0.2 & 0 & 0.1 & 18 & 11 & 18 & 0 & 0 & 0 & 0 & 0 & 0 \\
\hline $\mathrm{N} 12$ & 0.1 & 0.2 & 0 & 9.5 & 5.4 & 7.2 & 0 & 0 & 0 & 0 & 0 & 0 \\
\hline
\end{tabular}

* Meet NAMHG criteria.

$\mathrm{CSC}=$ Caffeine specific concentration; $\mathrm{S}=$ Patients diagnosed as $\mathrm{MH}$-susceptible; $\mathrm{N}=$ Patients diagnosed as $\mathrm{MH}$ non-susceptible .

coxon rank-sum test was applied to compare the effect of cocaine on baseline tension in $\mathrm{MH}$-susceptible and MH non-susceptible patients. A $P$ value $<0.05$ was considered statistically significant.

\section{Results}

\section{Diagnosis}

The 3\% halothane and caffeine contracture tests indicated that ten patients were MH-susceptible. Twelve patients were diagnosed as MH-non-susceptible (Table). Sex did not differ between groups: six men and four women were MH-susceptible and seven men and five women were MH-non-susceptible. Age also did not differ between groups: MH-susceptible, $25.3 \pm 10 \mathrm{yr}$; MH-nonsusceptible, $29.8 \pm 9.8$ yr (mean $\pm \mathrm{SD}$ ).

\section{$1 \%$ halothane contracture test}

Cocaine alone did not change baseline tension in any of the muscle strips in either group. However, it markedly decreased the twitch response (Figure 1). The \% decrease of twitch height did not differ between groups: $\mathrm{MH}$ susceptible, $49 \pm 15 \%$; $\mathrm{MH}$ non-susceptible, $55 \pm 15 \%$ (mean $\pm \mathrm{SD}$ ).
Cocaine had virtually no effect on baseline tension during administration of $1 \%$ halothane (Figure 2). However, in the presence of $1 \%$ halothane alone, strips from two MH-susceptible patients showed strong contractures that decreased when cocaine was added. Strips from two other MH-susceptible patients showed strong contractures when $1 \%$ halothane was added after cocaine but showed no contracture with $1 \%$ halothane alone. Eight other muscle strips from $\mathrm{MH}$-susceptible patients showed no response to $1 \%$ halothane in either the presence or absence of cocaine (Figure 2A). No muscle strips from $\mathrm{MH}$ non-susceptible patients showed contracture in response to $1 \%$ halothane in either the presence or absence of cocaine (Figure 2B). The responses to $1 \%$ halothane of MH-susceptible patients were larger than that of $\mathrm{MH}$ non-susceptible patients both in the presence and absence of cocaine (without cocaine, $P=0.01$; with cocaine, $P=0.047$ ).

\section{Discussion}

The calcium agonist, BAY $\mathrm{K} 8644$, potentiates the halothane-induced contracture of malignant hyperthermic muscle fibres. ${ }^{12,13}$ Calcium channel blockers, such as verapamil, diltiazem, and nifedipine suppress 


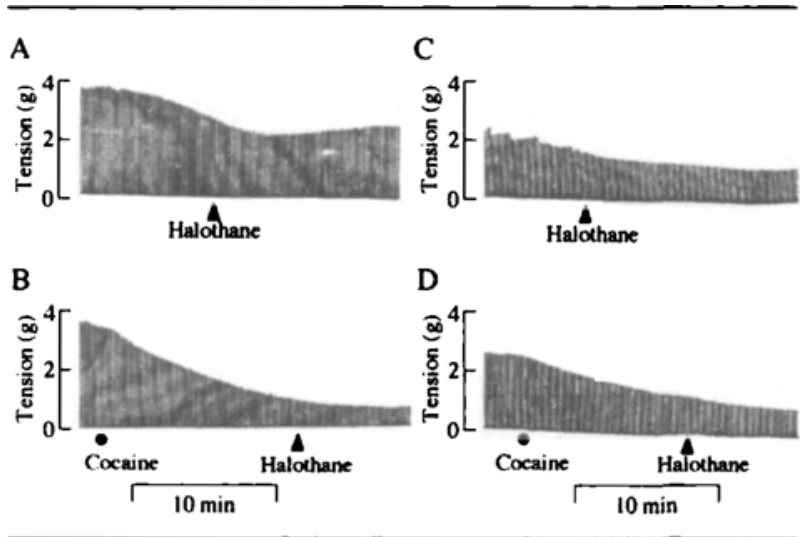

FIGURE I Representative tracings of contractures during $1 \%$ halothane administration in muscle strips from a MH non-susceptible patient (A,B) and a susceptible patient (C,D). Cocaine administration reduced the iwitch height in both patients. However, no apparent change was observed in the baseline tension in either group after cocaine administration (B,D). Furthermore, $1 \%$ halothane also showed no contracture in the presence (B,D) or absence $(A, C)$ of cocaine in both patients.

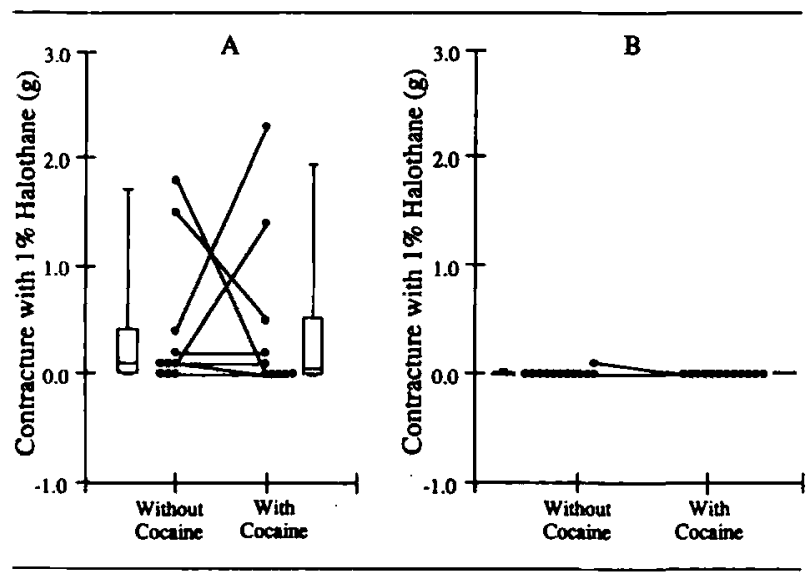

FIGURE 2 Change in baseline tension after administration of $1 \%$ halothane in the absence (without cocaine) and presence (with cocaine) of cocaine in MH susceptible patients $(A, n=10)$ and non-susceptible patients (B, $n=12$ ). The box plot shows the interquartile range, with the middle line representing the median. The bottom and top of the bar represents $10 \%$ and $90 \%$ respectively.

halothane-induced contractures in MH-susceptible patients. ${ }^{14.15}$ The effects of these drugs on calcium release and uptake mechanisms in the muscle cell appear to play an important role in their effects on muscle strips from MH-susceptible patients.

Cocaine at concentrations $<0.1 \mathrm{mmol} \cdot \mathrm{L}^{-1}$ causes coronary and aortic smooth muscle contraction, which may be mediated by increases in intracellular calcium. 16,17 Therefore, in the MH susceptible patient, it has been speculated that cocaine further deranges the already abnormal handling of calcium. Combining the two case reports cited in the introduction and the effect of cocaine on calcium handling discussed above, we expected that cocaine might potentiate the baseline tension and/or the contracture induced by $1 \%$ halothane. However, in our experiment cocaine affected neither the baseline tension nor the muscle contracture induced by $1 \%$ halothane. Therefore, cocaine does not have effects on the skeletal muscle of $\mathrm{MH}$-susceptible patients.

In our study, the direct effects of cocaine on skeletal muscle were observed with the preparations under baseline tension and in the presence of $1 \%$ halothane. We used $1 \%$ halothane as a "weak trigger" to verify if cocaine could have any additive or synergistic effect. Because $3 \%$ halothane causes strong contractures in muscle from $\mathrm{MH}$ susceptible patients it would be difficult to evaluate the effect of weak triggers in its (3\% halothane) presence. Indeed, because the caffeine contracture test alone may have a high false-negative rate, some laboratories use caffeine in the presence of $1 \%$ halothane. ${ }^{18}$ Furthermore, Britt $e t$ al. ${ }^{19}$ used only $0.8 \%$ halothane in their study that compared the combined effects of several inhalational anaesthetics on caffeine-induced contractures of muscle from normal and $\mathrm{MH}$-susceptible patients.

Escobedo et al. ${ }^{20}$ reported that subjects who died after smoking crack (chemically purified, very potent cocaine in pellet form which is smoked through a glass pipe) or free-base cocaine had lower blood cocaine levels at autopsy than subjects who died as a result of using cocaine hydrochloride. They also reported that blood cocaine hydrochloride concentrations were $>0.1$ $\mathrm{mmol} \cdot \mathrm{L}^{-1}$ at autopsy. The concentration of cocaine hydrochloride used in our experiments is equivalent to the plasma concentrations in these patients with cocaine intoxication.

It was previously thought that amide local anaesthetics were contraindicated in $\mathrm{MH}$-susceptible patients ${ }^{10}$ because they enhance contraction coupling of skeletal muscle. ${ }^{21}$ However, in MH-susceptible pigs, high doses of intravenous lidocaine caused systemic toxicity but no evidence of a MH crisis. 22 Indeed, mepivacaine and lidocaine, both amide anaesthetics, have been used successfully in MH-susceptible patients and swine. ${ }^{23,24}$ Amide local anaesthetics have proved safe for MH-susceptible patients. ${ }^{10}$ Our results suggest that cocaine, one of the ester local anaesthetics, also is safe for MH-susceptible patients.

Our results show that cocaine, even in toxic levels, does not affect the baseline tension and response to $1 \%$ halothane in muscle strips from MH-susceptible patients. These results indicate that cocaine may not trigger $\mathrm{MH}$ crisis directly at skeletal muscle and that cocaine can be used for $\mathrm{MH}$-susceptible patients in clinical practice. 


\section{Acknowledgements}

The authors thank Gisela Bunge BA, for her technical support; Angelo A. Licatta MD, PhD, of the Cleveland Clinic Ethical Committee for his suggestion regarding the ethical matters of representing patients; Cassandra Talerico for her editorial support.

\section{References}

1 Loghmanee $F$, Tobak $M$. Fatal malignant hyperthermia associated with recreational cocaine and ethanol abuse. Am J Forensic Med Pathol 1986; 7: 246-8.

2 Britt $B A$. Combined anesthetic- and stress-induced malignant hyperthermia in two offspring of malignant hyperthermia-susceptible parents. Anesth Analg 1988; 67: 393-9.

3 Gronert GA. Malignant hyperthermia. Anesthesiology 1980; 53: 395-423.

4 Pan $T-H$, Wollack $A R$, DeMarco JA. Malignant hyperthermia associated with enflurane anesthesia: a case report. Anesth Analg 1975; 54: 47-9.

5 Caropreso PR, Gittleman MA, Reilly DJ, Patterson LT. Malignant hyperthermia associated with enflurane anesthesia. Arch Surg 1975; 110: 1491-3.

6 McGuire $N$, Easy $W R$. Malignant hyperthermia during isoflurane anaesthesia. Anaesthesia 1990; 45: 124-7.

7 Thomas DW, Dev VJ, Whitehead MJ. Malignant hyperthermia and isoflurane. A case report. Br J Anaesth 1987; 59: 1196-8.

8 Ochiai R, Toyoda Y, Nishio I, et al. Possible association of malignant hyperthermia with sevoflurane anesthesia. Anesth Analg 1992; 74: 616-8.

9 Otsuka H, Komura Y, Mayumi T, Yamamura T, Kemmotsu $O$, Mukaida $K$. Malignant hyperthermia during sevoflurane anesthesia in a child with central core disease. Anesthesiology 1991; 75: 699-701.

10 Gronert GA, Schulman $S R$, Mott J. Malignant hyperthermia. In: Miller RD (Ed.). Anesthesia, 3rd ed. New York: Churchill Livingstone, 1990: 935-56.

11 Larach MG (North American Malignant Hyperthermia Group). Standardization of the caffeine-halothane muscle contracture test. Anesth Analg 1989; 69: 511-5.

12 Adnet PJ, Krivosic-Horber RM, Haudecoeur G, et al. Use of the calcium agonist BAY K 8644 for in vitro diagnosis of susceptibility to malignant hyperthermia. $\mathrm{Br} \mathrm{J}$ Anaesth 1990; 65: 79.1-5.

13 Williams JH, Holland M, Lee JC, Ward CW, McGrath CJ. BAY K 8644 and nifedipine alter halothane but not caffeine contractures of malignant hyperthermic muscle fibers. Am J Physiol 1991; 261: R782-6.

14 Adnet PJ, Krivasic-Horber RM, Adamantidis MM, Haudecoeur G, Reyfon GH, Dupuis BA. Clinical concentrations of verapamil affect the in vitro diagnosis of suscep- tibility to malignant hyperpyrexia. Br J Anaesth 1990; 64: 64-6.

15 Adnet PJ, Krivosic-Horber RM, Haudecoeur G, Reyford $H G$, Adamantidis MM, Dupuis BA. Diltiazem and nifedipine reduce the in vitro contracture response to halothane in malignant hyperthermic-susceptible muscle. Can J Anaesth 1990; 37: 556-9.

16 Foy RA, Myles $J L$, Wilkerson RD. Contraction of bovine coronary vascular smooth muscle induced by cocaine is not mediated by norepinephrine. Life Sci 1991; 49: 299-308.

17 Egashira K, Morgan KG, Morgan JP. Effects of cocaine on excitation-contraction coupling of aortic smooth muscle from the ferret. J. Clin Invest 1991; 87: 1322-8.

18 Rosenberg H, Fletcher J, Seitman D. Pharmacogenetics. In: Barash PG, Cullen BF, Stoelting RK (Eds.). Clinical Anesthesia, 2nd ed. New York: J.B. Lippincott Company, 1990; 589-613.

19 Britt BA, Endrenyl L, Frodis W, Scott E, Kalow W. Comparison of effects of several inhalational anaesthetics on caffeine-induced contractures of normal and malignant hyperthermic skeletal muscle. Can Anaesth Soc J 1980;27: 12-5.

20 Escobedo LG, Ruttenber AJ, Agocs MM, Anda RF, Wetli $C V$. Emerging patterns of cocaine use and the epidemic of cocaine overdose deaths in Dade County, Florid. Arch Pathol Lab Med 1991; 115: 900-5.

21 Bianchi CP, Bolton TC. Action of local anesthetics on coupling systems in muscle. J Pharmacol Exp Ther 1967; 157: 388-405.

22 Wingard $D W$, Bobko $S$. Failure of lidocaine to trigger porcine malignant hyperthermia. Anesth Analg 1979; 58 : 99-103.

23 Berkowitz A, Rosenberg $H$. Femoral block with mepivacaine for muscle biopsy in malignant hyperthermia patients. Anesthesiology 1985; 62: 651-2.

24 Kerr DD, Wingard DW, Gatz EE. Prevention of porcine malignant hyperthermia by epidural block. Anesthesiology 1975; 42: 307-11. 